\title{
Seasonal changes in the photosynthetic performance of two evergreen Nothofagus species in south central Chile
}

\author{
Cambios estacionales en el desempeño fotosintético de dos especies \\ siempreverdes de Nothofagus en el centro sur de Chile
}

\section{RAFAEL ZÚNIIGA ${ }^{1}$, MIREN ALBERDI $^{1} *$, MARJORIE REYES-DÍAZ ${ }^{2}$, ERICK OLIVARES ${ }^{1}$, SUSAN HESS $^{3}$, LEÓN A. BRAVO ${ }^{2} \&$ LUIS J. CORCUERA ${ }^{2}$}

\author{
${ }^{1}$ Instituto de Botánica, Facultad de Ciencias, Universidad Austral de Chile, Casilla 567, Valdivia, Chile \\ ${ }^{2}$ Departmento de Botánica, Facultad de Ciencias Naturales y Oceanográficas, \\ Universidad de Concepción, Concepción, Casilla 160 C, Chile \\ ${ }^{3}$ Instituto de Química, Facultad de Ciencias, Universidad Austral de Chile, Casilla 567, Valdivia, Chile \\ *e-mail for correspondence: malberdi@uach.cl
}

\begin{abstract}
The evergreen Nothofagus dombeyi and Nothofagus nitida are important members of the temperate Chilean rainforest. They seldom grow together in nature. Nothofagus nitida is more susceptible to excess light and drought than $N$. dombeyi. We postulate that the different properties of the photosynthetic apparatus under common garden conditions of these species could explain their contrasting habitat preferences. The two species growing in a common garden in south central Chile were studied. The optimal photochemical efficiency $(\mathrm{Fv} / \mathrm{Fm})$ of both species remained within normal values $(\approx 0.8)$ with the exception of a decrease in $N$. dombeyi at midday in summer, suggesting reversible reduction in photochemical efficiency of photosystem II (PSII). During summer the effective photochemical efficiency $\left(\Phi_{\mathrm{PSII}}\right)$, photochemical quenching $(\mathrm{qP})$, photosynthesis $\left(\mathrm{A}_{\max }\right)$, stomatal conductance $(\mathrm{gs})$ and transpiration rates $(\mathrm{E})$ in $N$. dombeyi were higher than in $N$. nitida. The highest increments in photoprotective pigments (zeaxanthin + antheraxanthin and lutein) contents between predawn and midday were obtained in summer in $N$. dombeyi. In $N$. nitida a nocturnal retention of dissipative pigments, without a decrease in $\mathrm{Fv} / \mathrm{Fm}$, was found in winter. The results suggest that $N$. dombeyi showed a better photosynthetic performance than $N$. nitida under high light, high temperature, and drier conditions. These data support are consistent with the pioneer character of $N$. dombeyi and the semitolerant shade properties and more restricted distribution of $N$. nitida. These photosynthetic characteristics, along with their freezing and flooding resistance differences, may result from their habitat separation.
\end{abstract}

Key words: chlorophyll fluorescence, photosynthesis, Nothofagus dombeyi, Nothofagus nitida, xanthophyll cycle.

\section{RESUMEN}

Las siempreverdes, Nothofagus dombeyi y Nothofagus nitida, representantes importantes de los bosques lluviosos templados de Chile, raramente crecen juntos en forma natural. Nothofagus nitida es más sensible al exceso de luz y déficit de agua que $N$. dombeyi. Se postula que diferentes propiedades del aparato fotosintético bajo condiciones de jardín común de estas especies podrían explicar sus contrastantes preferencias de hábitat. Se estudian algunas de estas propiedades en estas dos especies creciendo en un jardín común en el centro sur de Chile. La eficiencia fotoquímica máxima $(\mathrm{Fv} / \mathrm{Fm})$ de ambas especies permanece en el rango de los valores normales $(\approx 0,8)$ con excepción de un decrecimiento al mediodía y en verano en $N$. dombeyi, que sugiere una reducción reversible de la eficiencia fotoquímica máxima del fotosistema II (PSII). Durante el verano, la eficiencia fotoquímica efectiva del PSII $\left(\Phi_{\mathrm{PSII}}\right)$, el apagamiento fotoquímico (qP), la fotosíntesis $\left(\mathrm{A}_{\max }\right)$, conductancia estomática $(\mathrm{gs})$ y las tasas de transpiración (E) en $N$. dombeyi fueron mayores que en $N$. nitida. Los mayores incrementos en los contenidos de pigmentos fotoprotectores (zeaxantina + anteraxantina y luteína) entre prealba y mediodía se obtuvieron en verano en $N$. dombeyi . En $N$. nitida se presentó en invierno una retención nocturna de zeaxantina sin decrecimiento de $\mathrm{Fv} / \mathrm{Fm}$. Los resultados sugieren que bajo condiciones de mayor intensidad lumínica, mayor temperatura y sequía, $N$. dombeyi mostró un mejor desempeño fotosintético que $N$. nitida. Los datos presentados son consistentes con la capacidad pionera de $N$. dombeyi y las propiedades de semitolerancia a la sombra y distribución más restringida de $N$. nitida. Estas características fotosintéticas, junto con las diferencias de la resistencia al congelamiento, sequía y anegamiento pueden resultar de su separación de hábitat.

Palabras clave: fluorescencia de la clorofila, fotosíntesis, Nothofagus dombeyi, Nothofagus nitida, ciclo de las xantófilas. 


\section{INTRODUCTION}

Nothofagus species are important members of the south central Chilean temperate rainforest between the $37-43^{\circ} \mathrm{S}$ (Alberdi et al. 1985). The climate where these species dominate is generally defined as Mediterranean-humid with oceanic tendency (Di Castri \& Hajek 1976). Despite the oceanic tendency of the climate, low temperature and frost can occur in winter, spring and summer, which can impose soil drought conditions (Weinberger et al. 1973). In these seasons, frost is frequently followed by markedly clear and cold days (Alberdi et al. 1985). In summer, sporadic drought periods can also occur in some habitats, which are accompanied by high irradiance (Weinberger 1973). Cabrera (2006) reported that water stress could be a determinant factor in the distribution of evergreen and semideciduous trees in Mediterranean ecosystems.

Nothofagus dombeyi (Mirb.) Oerst. and Nothofagus nitida (Phil.) Krasser are evergreen species in the southern Chilean forest. These species have different latitudinal and altitudinal distribution in south central Chile, and they don't usually grow naturally together (Weinberger 1973). Nothofagus dombeyi is distributed in Chile between the $34^{\circ} 37^{\prime}$ to $47^{\circ} 30^{\prime} \mathrm{S}$ in the Andes and the costal range and intermediate depression, while $N$. nitida is distributed between $40^{\circ} 20^{\prime}$ to $48^{\circ} 30^{\prime} \mathrm{S}$, especially in the coastal range (Weinberger 1973, Veblen et al. 1996). Both species have similar low altitudinal distribution (near sea level), but $N$. dombeyi attains a higher altitude (about $1,800 \mathrm{~m}$ of altitude) than $N$. nitida (about $900 \mathrm{~m}$ of altitude). Nothofagus dombeyi is a typical heliophyte and can be a pioneer tree in unfavorable Andean mountain habitats, such as "Lahares" (areas without vegetation formed by volcanic scoria, subjected to high radiation and drought during the day and low temperatures at night) (Mc Queen 1977, Veblen et al. 1995). Nothofagus nitida is a shade semitolerant species (Donoso \& Lara 1998). This species regenerates in shade stands with constant humidity and intermediate thermal conditions in the coastal region, showing a special adaptation to wet and flooding soils (Veblen et al. 1996). Nothofagus dombeyi regenerates in well drained open habitats (Weinberger 1973). Nothofagus dombeyi is more cold and drought resistant than $N$. nitida (Weinberger et al. 1973, Reyes-Díaz et al. 2005). These properties, along with the higher capacity of $N$. dombeyi to form hybrids, could explain the wider latitudinal and altitudinal distribution of N. dombeyi (Veblen et al. 1996).

Another important factor that may also contribute to their habitat separation may be the properties of their photosynthetic apparatus such us capacity to manage light and dissipation mechanisms for excess light energy. In many species, perturbations of the photosynthetic apparatus by excess light or in combination with other stresses (e.g., drought or cold) are first manifested in alterations in the photochemical efficiency of photosystem II (PSII) and therefore, in net photosynthetic rates (Larcher 2000). The xanthophylls cycle is the major mechanism for thermal dissipation of excess energy under high light. It has fundamental role, decreasing photoinhibitory damage during environmental stresses which impose a high excitation pressure on the photosynthetic apparatus due to their effect on stomatal conductance and $\mathrm{CO}_{2}$ assimilation (Niyogi 1999). Zeaxanthin (Z) and perhaps also antheraxanthin (A) are needed for the reactions that actually do the dissipation of the surplus energy present in the pigment bed of light harvesting complexes (Külheim et al. 2002, Demmig-Adams 2003, Pascal et al. 2005).

When a combination of light and water stress occurs, Nerium oleander shows high dissipation of light energy by an accumulation of $\mathrm{Z}$ (Demmig et al. 1988). However, in Lavandula stoechas growing under field conditions, the xanthophylls cycle is induced by light irrespective of the water status (Munné-Bosch \& Alegre 2000). GarcíaPlazaola et al. (1997) found higher concentrations in the xanthophylls pool in Quercus suber leaves when photosynthesis was limited by water and cold stress by the end of summer and winter, respectively. Lutein (L) has been also proposed as modulator of the rate of thermal energy dissipation (Müller et al. 2001, Standfuss et al. 2005).

Another strategy to decrease the impact of excess light experienced by species that maintain their leaves in winter may be the decrease in chlorophyll content, which can lower the light harvesting capacity of the leaves 
by diminishing photon absorption (Adams \& Barker 1998, Adams et al. 2004).

With exception of the work by Lusk \& Del Pozo (2002), which reported the photosynthesis of $N$. dombeyi and $N$. nitida growing under controlled conditions, no attention has been paid to the photosynthetic performance and to the participation of the xanthophylls cycle in energy dissipation of leaves in evergreen Nothofagus species from the Chilean temperate forest under possible photoinhibitory climatic conditions, prevailing in their habitats. In this paper, we will follow the seasonal changes in the photosynthetic performance (net photosynthesis and photochemical efficiency of the PSII) in relation to photoprotective pigments of the xanthophylls cycle in leaves of two evergreen woody Nothofagus species, growing in a common garden in south central Chile. Additionally, leaf physiological parameters (transpiration, stomatal conductance, water use efficiency, osmotic potential) and solute accumulation (total soluble carbohydrates and free proline) as indicators of the water status of plants were determined, This is the first comprehensive field study of photosynthesis in evergreens of the Chilean temperate rainforest, giving some of the physiological basis for the habitat preferences of the two main dominant species of this threatened rainforest.

\section{MATERIAL AND METHODS}

\section{Study area and plant material}

This study was performed in a $N$. nitida forest stand in Pichiquillaipe, 10th Administrative

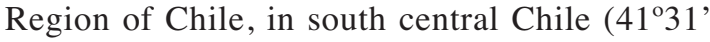
$\left.\mathrm{S}, 72^{\circ} 45^{\prime} \mathrm{W}\right)$, where this species grows naturally. Adjacent to this site, in 1994, around 50 two year old seedlings of $N$. nitida, from this forest, and around $50 \mathrm{~N}$. dombeyi, from a forest located in San Pablo de Tregua in Panguipulli (Provincia de Valdivia at $39^{\circ} 38^{\prime} \mathrm{S}$, $72^{\circ} 09^{\prime} \mathrm{W}$ ), in south central Chile with similar climatic characteristics as the study area (Reyes-Díaz et al. 2005), were randomly planted in the study site. At the beginning of the establishment, seedlings were surrounded by adjacent low vegetation (especially grasses and small shrubs). Since this study was conducted from winter 2003 (July) to early autumn (March) 2004, the trees used were 11 years old (late juvenile phase). Five individuals of each species were randomly selected and marked to make repeated measurements throughout the year. Fully developed leaves from the leaf cohort emerged in the spring 2002, at similar height and NE exposure were used for the determinations. Daily maximum and minimum temperatures, precipitation, and photosynthetic photon flux densities (PPFD) were determined in the study site with a Licor data logger (LI-1400) equipped with sensors for air temperature and relative humidity (LI 1400-104), rain (LI 1400-106) and PPFD (LI190SA quantum sensor). Climatic conditions of the 15 days prior to the sampling days are presented. Daily PPFD changes on leaves where the determinations were made and in an adjacent open field were measured. Measured and collected leaves were exposed to similar PPFD each season.

Physiological measurements were made seasonally and daily, at predawn, midday (maximum incident PPFD, 12-14 h) and afternoon (two hours before sunset). Photosynthesis measurements were initiated in the morning (two to three hours after sunrise). For chemical analyses, individually collected leaves were immediately frozen in liquid nitrogen and stored at $-80{ }^{\circ} \mathrm{C}$.

\section{Net photosynthesis}

An infrared gas analyzer (Ciras-1, PP system; Hitchin, United Kingdom) was used to estimate net $\mathrm{CO}_{2}$ assimilation rates $\left(\mathrm{A}_{\max }\right)$ on attached leaves. External air was scrubbed of $\mathrm{CO}_{2}$ and mixed with a supply of pure $\mathrm{CO}_{2}$, to result in a reference concentration of $360 \mathrm{ppm}$, with a flow rate of $200 \mathrm{~mL} \mathrm{~min}^{-1}$ and $80 \%$ external relative humidity. The temperature inside the leaf chamber was maintained at 15 ${ }^{\circ} \mathrm{C}$. This value was selected because previous determinations at different temperatures indicated that $15{ }^{\circ} \mathrm{C}$ is in the range of the optimum temperature for photosynthesis in these species. The relative humidity value is representative of the usual humidity in the study site, as indicated by the measurements with the Licor data logger (LI-1400). Outdoor light intensities at the moment of the measurements were used to achieve steady- 
state photosynthesis. This instrument also allows one to calculate other physiologic parameters such us transpiration (E), stomatal conductance (gs), and instantaneous water use efficiency of photosynthesis (WUE). The WUE corresponds to the quotient between $\mathrm{A}_{\max }$ and $\mathrm{E}$.

\section{Chlorophyll fluorescence parameters}

Fluorescence signals were generated by a pulse-amplitude modulated fluorimeter (FMS 2, Hansatech Instruments Ltd., Norfolk, United Kingdom). Attached leaves of both species were dark adapted for $30 \mathrm{~min}$ (preliminary measurements indicated no differences in $\mathrm{Fv} / \mathrm{Fm}$ with longer adaptations periods or greater irradiance) with leaf-clips with a mobile shutter plate. The fiber-optic and its adapter were fixed to a ring located over the clip at about $10 \mathrm{~mm}$ from the sample and different light pulses (see below) were applied following the standard routines programmed within the equipment. Signal recordings and calculations were performed using the data analyses and control software provided by the manufacturers (Hansatech Instruments Ltd., Norfolk, United Kingdom). According to the terminology of van Kooten \& Snel (1990), minimal or initial fluorescence (Fo) was determined applying a weak modulated light $\left(0.4 \mu \mathrm{mol}\right.$ photons $\left.\mathrm{m}^{-2} \mathrm{~s}^{-1}\right)$ and maximal fluorescence $(\mathrm{Fm})$ was induced in dark adapted leaves by a short pulse $(0.8 \mathrm{~s})$ of saturating light (around 9,000 $\mu \mathrm{mol}$ photons $\left.\mathrm{m}^{-2} \mathrm{~s}^{-1}\right)$. Shortly after relaxation of Fm actinic light was turned on $\left(500 \mu \mathrm{mol}\right.$ photons $\mathrm{m}^{-2} \mathrm{~s}^{-}$ $\left.{ }^{1}\right)$. This light intensity corresponded to the mean obtained by light response curves for both species. Both species were saturated at this light intensity, but they were not photoinhibited. Then, the same saturating pulse described previously was applied every $20 \mathrm{~s}$, until steady state photosynthesis was reached in order to obtain Fs and Fm'. Finally, Fo' was measured after turning the actinic light off and applying a $2 \mathrm{~s}$ far red light pulse. Definitions of fluorescence parameters ( $\mathrm{qP}$, NPQ, Fv/Fm and $\left.\Phi_{\text {PSII }}\right)$ were used as described by van Kooten \& Snel (1990). Fv/Fm and $\Phi_{\mathrm{PSII}}=(\mathrm{Fm}$ ' $-\mathrm{Fs}) / \mathrm{Fm}$ ' are indicators of the maximum and effective quantum yield of the PSII (Genty et al. 1989) respectively.
Photochemical quenching (qP) was calculated as: $\mathrm{qP}=\left(\mathrm{Fm}^{\prime}-\mathrm{Fs}\right) /\left(\mathrm{Fm}{ }^{\prime}-\mathrm{Fo}{ }^{\prime}\right)$, with $\mathrm{Fm}{ }^{\prime}$ being the maximal fluorescence in light adapted leaves, and Fs the steady state fluorescence yield. Non photochemical quenching was calculated as: $\mathrm{NPQ}=(\mathrm{Fm}-$ Fm')/Fm'.

\section{Pigment determinations}

Chlorophylls, carotenoids and xanthophylls determinations were made with spectroscopic and chromatographic techniques. For chlorophylls and total carotenoids determinations, $100 \mathrm{mg}$ of fresh weight foliar tissue of both species were placed in a cold mortar with a minimal amount of $\mathrm{CaCO}_{3}$ and ground with $80 \%(\mathrm{v} / \mathrm{v})$ acetone at $4{ }^{\circ} \mathrm{C}$ under dim light. Pigments extracts were measured in a spectrophotometer (Metertek SP 850, Taipei, Taiwan) at 663, 646 and $470 \mathrm{~nm}$. Pigments concentrations were calculated according to Lichtenthaler \& Welburn (1983).

Xanthophylls were determined by phase reversed, solvent gradient, high performance liquid chromatography (HPLC, Hewlett Packard 1100, Agilent Technologies Inc., San José, California, USA). $100 \mathrm{mg}$ of fresh weight foliar tissue were powdered with liquid nitrogen in a cold mortar and extracted with methanol. The homogenate was centrifuged at 0 ${ }^{\circ} \mathrm{C}$ for $3 \mathrm{~min}$ at $5,000 \mathrm{~g}$ and kept in ice. The supernatant fractions were pooled and adjusted to a final volume of $4 \mathrm{~mL}$ and filtered through a $0.2 \mu \mathrm{m}$ syringe filter (PTFE) and stored at $40^{\circ} \mathrm{C}$ until HPLC analysis. Then $50 \mu \mathrm{L}$ of extract were injected in a Luna $\mathrm{C} 18$ reversed phase HPLC column $(250$ x $4.60 \mathrm{~mm}$ i.d.; $5 \mu \mathrm{m}$ particle size) protected by a Phenomenex C18 guard column ( 4 x $3.0 \mathrm{~mm}$ i.d.). For separation a mobile phase consisted of two components: solvent A, acetonitrile:methanol:buffer Tris$\mathrm{HCl} 0.1 \mathrm{M} \mathrm{pH} 8.0$ (72:8:3) and solvent $\mathrm{B}$, methanol:ethyl acetate (68:32) following the protocol of Gilmore \& Yamamoto (1991) with some modifications was used. Pigments were eluted using a gradient of solvent A, running isocratically for $6 \mathrm{~min}$, followed by $10 \mathrm{~min}$ of a linear gradient up to $100 \%$ of the solvent mixture $\mathrm{B}$ and $4 \mathrm{~min}$ of isocratic mixture of the last solvent.

The amounts of violaxanthin (V), antheraxanthin (A), zeaxanthin (Z) were 
measured by using pure standards of these substances provided by DHI Water \& Environment, Copenhagen, Denmark. Lutein (L) standard were obtained from Sigma, (St. Louis, Missouri, USA). All standards were in ethanol. Concentrations of pigments were expressed on chlorophyll a basis. The conversion state was calculated as $(\mathrm{A}+\mathrm{Z}) /$ $(\mathrm{V}+\mathrm{A}+\mathrm{Z})$.

\section{Compatible solutes}

Free proline was determined colorimetrically according to Bates, Waldren \& Teare (1973). Carbohydrates were extracted from fresh leaf tissue in $86 \% \mathrm{v} / \mathrm{v}$ ethanol with overnight agitation. Total soluble carbohydrates (TSC) content was determined spectrophotometrically by the resorcinol method (Roe 1934) by measuring A520, using sucrose as standard.

\section{Statistics}

Two-way repeated measures analyses of variance (ANOVA) were used to test the effects and interactions of time (season and time of the day) and species on pigments, metabolites, chlorophyll fluorescence, net photosynthesis, and water status parameters. A Tukey test was used to identify those values with significant differences. Sigma Stat 2.0 software (SPSS Inc., Chicago, Illinois, USA) was used for both analyses. Differences between the values $(P \leq 0.05)$ were determined. Determinations are based on five replicates, corresponding to five individuals in each species.

\section{RESULTS}

\section{Climatic conditions}

The usual pattern of rainy winters and dry summers of southern Chile was reflected in the 15 days before determinations where winter precipitations were $79 \mathrm{~mm}$ and summer precipitations were $37 \mathrm{~mm}$ (Fig. 1A and 1C). Early autumn was exceptionally dry with a precipitation of $8 \mathrm{~mm}$ in the 15 days previous to the determinations (Fig. 1D). Temperatures near or below freezing in the preceding 15 days or at day of measurements were obtained in winter $\left(-0.9{ }^{\circ} \mathrm{C}\right.$ at 8 July and $-1.8{ }^{\circ} \mathrm{C}$ at $11 \mathrm{July}$ 2003) and in spring (around $-0.8{ }^{\circ} \mathrm{C}$ at 2 and 9 October 2003), while the highest absolute maximum temperature $\left(26.6{ }^{\circ} \mathrm{C}\right)$ was measured in January 2004 (Fig. 1A, 1B and 1C respectively). The highest PPFDs were observed between 12:00 and 14:00 $\mathrm{h}$ in all seasons, being the summer values around twice times higher than the winter values (about 2,000 and 1,000 $\mu \mathrm{mol} \mathrm{m} \mathrm{m}^{-2} \mathrm{~s}^{-1}$, respectively) (data not shown). Relative humidity at midday was not higher than $80 \%$. Thus, sampling days were all clear days in the four seasons, with normal temperatures for each season. Rainfall registered on March 31 (one of the sampling days) occurred several hours after sampling.

\section{Photosynthetic parameters}

The highest $\mathrm{A}_{\max }$ in $N$. dombeyi were obtained at midday and afternoon in summer $(\mathrm{P} \leq 0.05)$ (Fig. 2A), corresponding with increased gs (Fig. 2B). Differences in the daily course of $\mathrm{A}_{\max }$ in $N$. nitida were found in all seasons (Fig. 2E) corresponding the high values generally to midday ( $\mathrm{P} \leq 0.05)$. Statistical differences in the $A_{\max }$ values between the species were found in summer, winter and spring, being midday and afternoon values in summer the most important contrasts (around 1.5 times higher in $N$. dombeyi than in $N$. nitida) (Fig. 2A and 2E).

Higher gs were found in $N$. dombeyi at midday and morning in summer and autumn respectively ( $\mathrm{P} \leq 0.05$ ), while in $N$. nitida, the highest $\mathrm{gs}$ was obtained in the afternoon in autumn and at midday in winter. These last values were statistically significant different to those obtained at the same time in $N$. dombeyi, coinciding with a high $\mathrm{A}_{\max }$ (Fig. 2B and 2F).

Seasonal E values were generally very similar in both species at each time of the day, with the exception of the summer values, which were significantly higher in $N$. dombeyi than in $N$. nitida $(\mathrm{P} \leq 0.05)$ (Fig. $2 \mathrm{C}$ and $2 \mathrm{G})$. The highest values of WUE in $N$. dombeyi were obtained at midday in spring and morning in summer. In $N$. nitida the highest values were also found in spring and summer. Differences between the WUE of both species were found in summer and spring being the values in $N$. dombeyi higher than in $N$. nitida (Fig. 2D and 2H). 

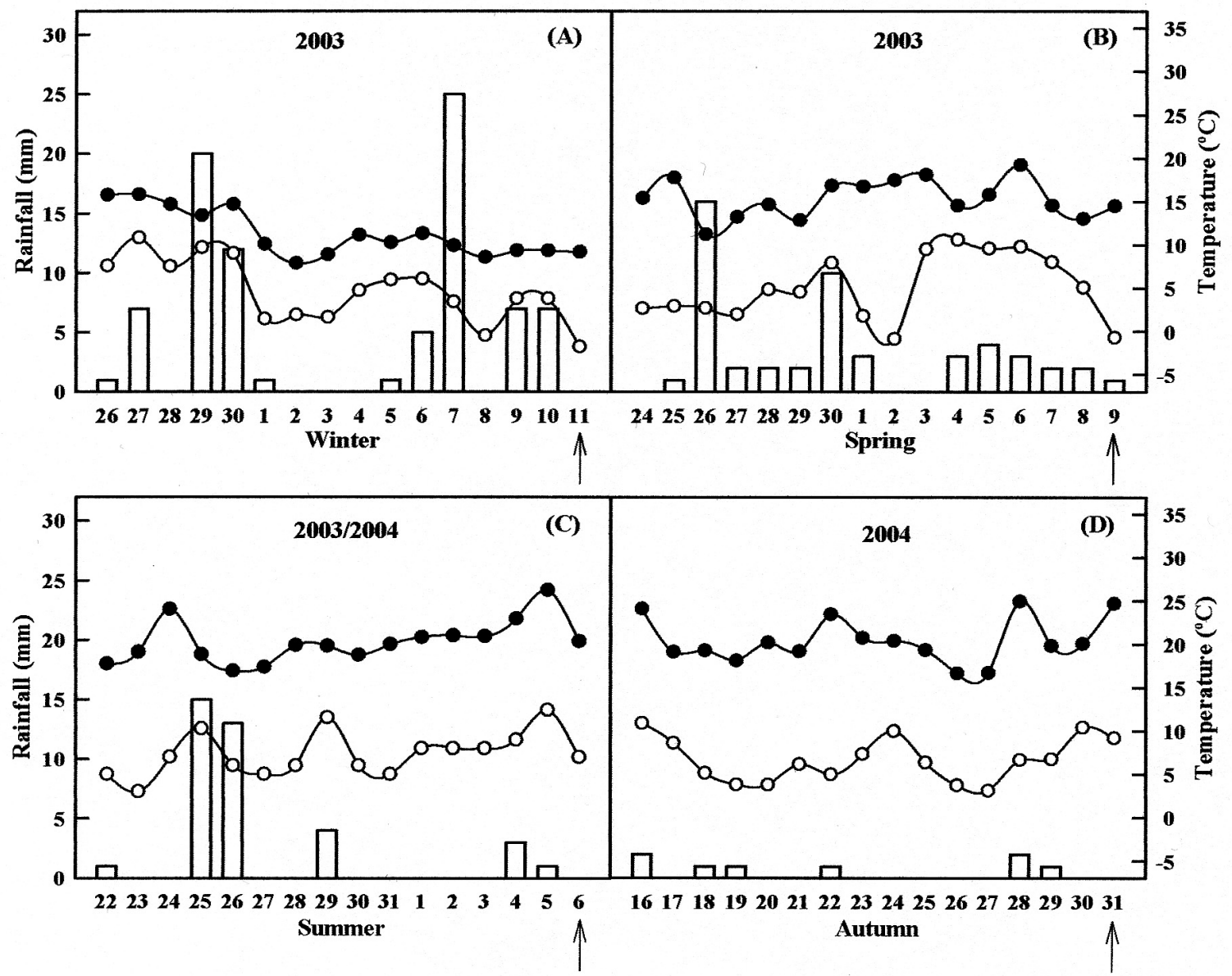

Fig. 1: Precipitations (bars) and maximum (•) and minimum (o) absolute air temperatures in the preceding 15 days to the sampling and measurements date (arrows) between April 2003 and March 2004. (A) Winter; (B) Spring; (C) Summer and (D) Autumn. Measurements were made at $2 \mathrm{~m}$ above the soil level.

Precipitaciones (barras), temperaturas del aire máximas (•) y mínimas (o) absolutas en los 15 días previos a las mediciones y toma de las muestras (flechas) entre abril 2003 y marzo del 2004. (A) Invierno; (B) Primavera; (C) Verano y (D) Otoño. Las mediciones fueron hechas a $2 \mathrm{~m}$ sobre el nivel del suelo.

\section{Chlorophyll fluorescence parameters}

Fv/Fm of leaves of both species was situated generally within physiologic normal values (around 0.85) during the annual and daily cycle (predawn, midday and afternoon), with exception of $N$. dombeyi leaves where statistically significant lower values than in $N$. nitida were obtained at midday in summer (Table 1).

Differences between the predawn and midday values of $\Phi_{\text {PSII }}$ were found in $N$. dombeyi, with highest values at midday and afternoon in summer $(\mathrm{P} \leq 0.05)$ (Table 1$)$. In $N$. nitida the highest value was found at afternoon in winter and the lowest during the afternoon in spring $(\mathrm{P} \leq 0.05)$. Statistically significant differences $(\mathrm{P} \leq 0.05)$ between species were found at midday in summer and autumn and in the afternoon in spring, summer, and autumn. $\Phi_{\text {PSII }}$ values were generally higher in $N$. dombeyi (Table 1).

The highest qP of leaves of $N$. dombeyi was found at midday and afternoon in summer $(\mathrm{P} \leq$ 0.05 ) (Table 1). In $N$. nitida the highest values were obtained at predawn, midday and afternoon in summer and afternoon in winter. Generally, N. dombeyi attained higher $\mathrm{qP}$ values than $N$. nitida $(\mathrm{P} \leq 0.05)$. Significant differences between species were found at predawn in autumn, at midday in spring, summer and autumn, and in the afternoon in winter summer and autumn. 


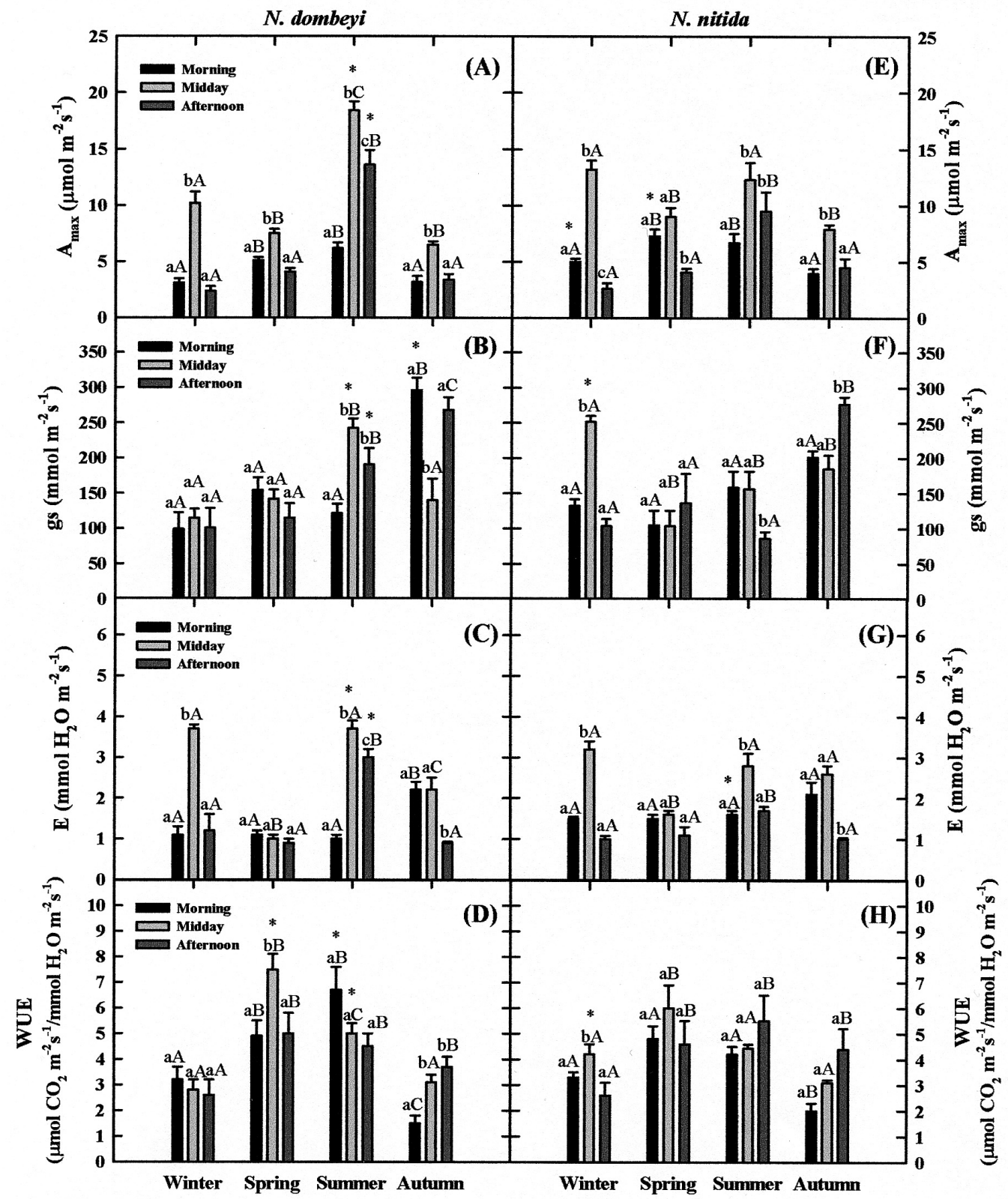

Fig. 2: Seasonal and daily photosynthetic parameters in leaves of $N$. dombeyi (A-D) and $N$. nitida $(E-H)$. The following parameters were measured in the photosynthetic chamber: $A_{\max }=\mathrm{CO}_{2}$ assimilation rate; $\mathrm{gs}=$ stomatal conductance; $\mathrm{E}=$ transpiration; and water use efficiency (WUE). The values are means of five replicates \pm SE. Different lower case letters indicate statistically significant differences $(\mathrm{P} \leq 0.05)$ between daily periods for each season and species. Different upper case letters show statistically significant differences $(P \leq 0.05)$ between seasons for each species in the same daily period. Asterisk $(*)$ indicate statistically significant differences $(\mathrm{P} \leq 0.05)$ between species for each parameter in the same season and hours of day.

Cambios estacionales y diarios de los parámetros fotosintéticos en hojas de $N$. dombeyi (A-D) and $N$. nitida (E-H) creciendo en el centro sur de Chile. En la cámara fotosintética se midieron los siguientes parámetros: $\mathrm{A}_{\max }=\mathrm{CO}_{2}$ tasa de asimilación; gs = conductancia estomática; $\mathrm{E}$ = transpiración y eficiencia en el uso del agua (WUE). Los valores son promedios de cinco réplicas \pm EE. Letras minúsculas diferentes indican diferencias estadísticamente significativas $(\mathrm{P} \leq$ $0,05)$ entre los períodos del día para cada estación y especie. Letras mayúsculas diferentes indican diferencias estadísticamente significativas $(\mathrm{P} \leq 0,05)$ entre las estaciones, para cada especie y en el mismo período del día. Asterisco (*) indica diferencias estadísticamente significativas $(\mathrm{P} \leq 0,05)$ entre las especies, para cada parámetro en la misma estación y hora del día. 


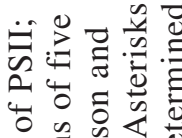

入

范

월

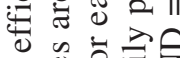

न

光票宁完

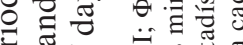

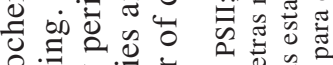

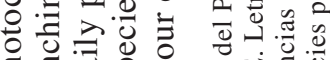

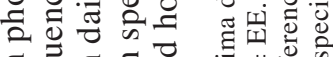

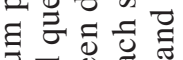

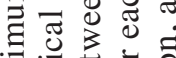

的造

远会出

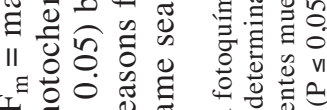

u

I

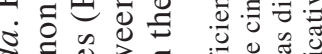

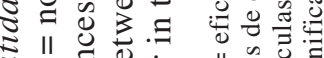

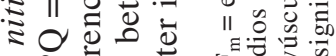

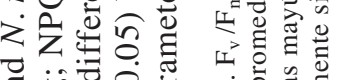

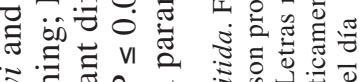

प्र ₹

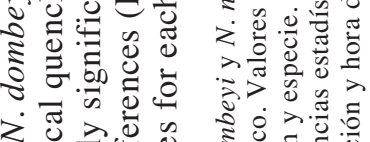

च न

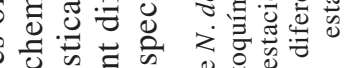

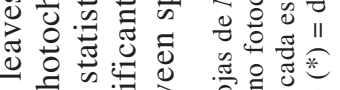
出

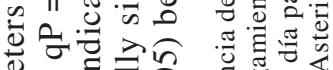

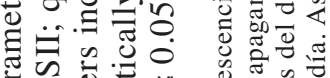

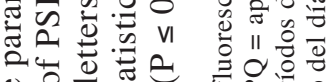
0. 它它感的 ठ․․

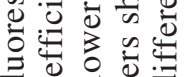
要远

$\Xi$.

s

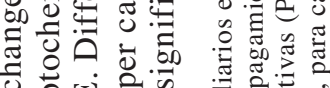

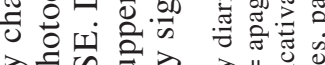

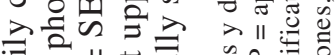
可证范

들

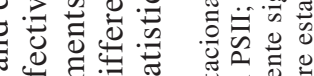

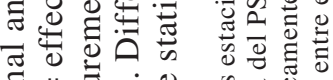

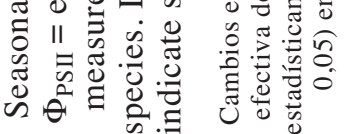

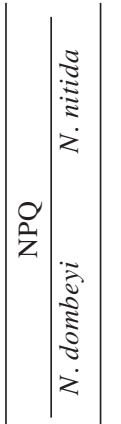

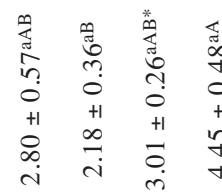

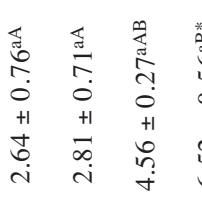

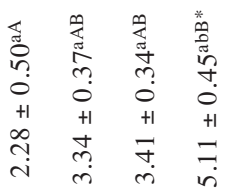

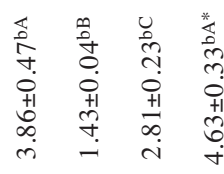

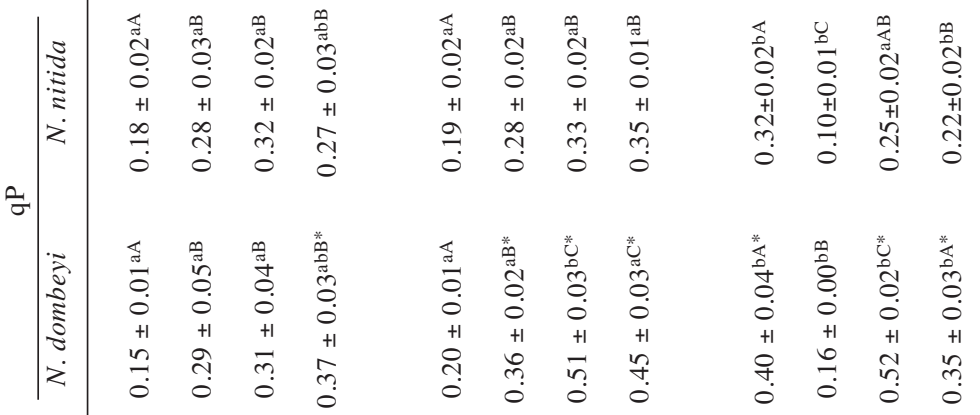

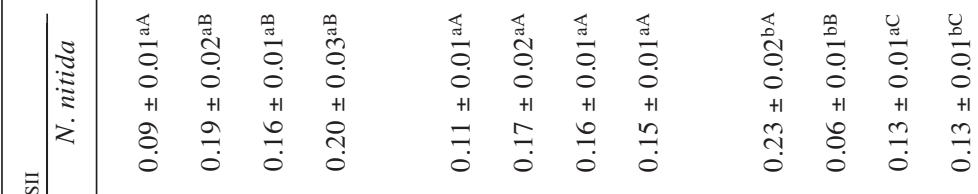

$\hat{\theta}$

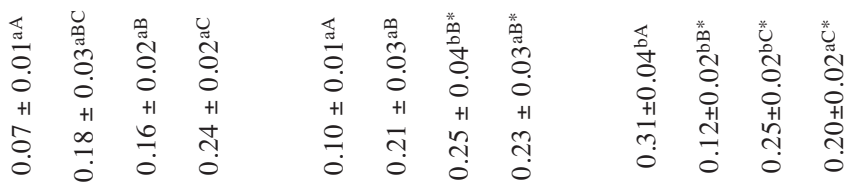

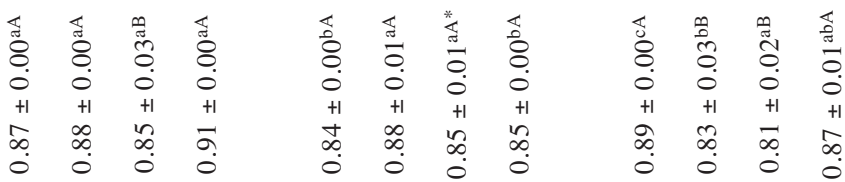

$\underbrace{2}_{12}$

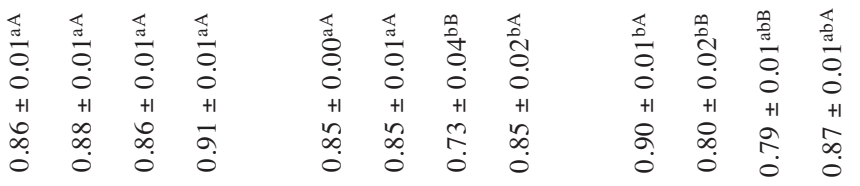

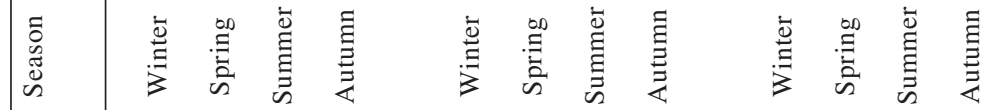


Since NPQ is frequently associated with the xanthophylls cycle, the seasonal and daily changes (predawn and midday) in NPQ and conversion state were determined. In both species, NPQ of leaves increased generally from winter to autumn $(\mathrm{P} \leq 0.05)$ (Table 1). A similar tendency was observed in conversion state at midday in $N$. dombeyi (Fig. 3A), while in N. nitida, it increased at midday from winter to summer, decreasing afterwards (Fig. 3B). No significant differences in the conversion state of $N$. dombeyi were found within seasons at predawn (Fig. 3A). In N. nitida, however, a decrease towards summer (Fig. 3B) was found. Conversion state of both species increased from predawn to midday in all seasons $(\mathrm{P} \leq 0.05)$ (Fig. 3A and 3B).

\section{Xanthophylls}

Values of $\mathrm{V}$ were higher at predawn in all seasons in both species than at other times of the day (Table 2). Concomitantly with the $\mathrm{V}$ decrease, an increase in $\mathrm{Z}$ contents occurred in $N$. dombeyi, being $\mathrm{Z}$ contents higher at midday than at predawn in all seasons (around 300 to $700 \%$ ). Statistically significant differences in $\mathrm{Z}$ contents between the species were found only in predawn, in winter and spring, presenting $N$. nitida higher values than $N$. dombeyi at those times. A contents were much lower than $\mathrm{Z}$ content in the two species. The total pool of xanthophylls $(\mathrm{V}+\mathrm{A}+\mathrm{Z})$ was higher in winter and lower in autumn than the other seasons. Nothofagus nitida showed higher $\mathrm{V}+\mathrm{A}+\mathrm{Z}$ in winter at midday than predawn (Table 2).

The content of L was lower than in other xanthophylls. Nothofagus dombeyi presented statistically significant $(\mathrm{P} \leq 0.05)$ higher $\mathrm{L}$ contents than $N$. nitida in winter at predawn and in spring and summer at midday (Table 2).

\section{Chlorophylls and total carotenoids}

No statistically significant differences in total chlorophyll and carotenoids contents of both species during daily periods on each season were obtained (Table 3). Chlorophyll a/b was generally slightly higher in $N$. dombeyi than in $N$. nitida.

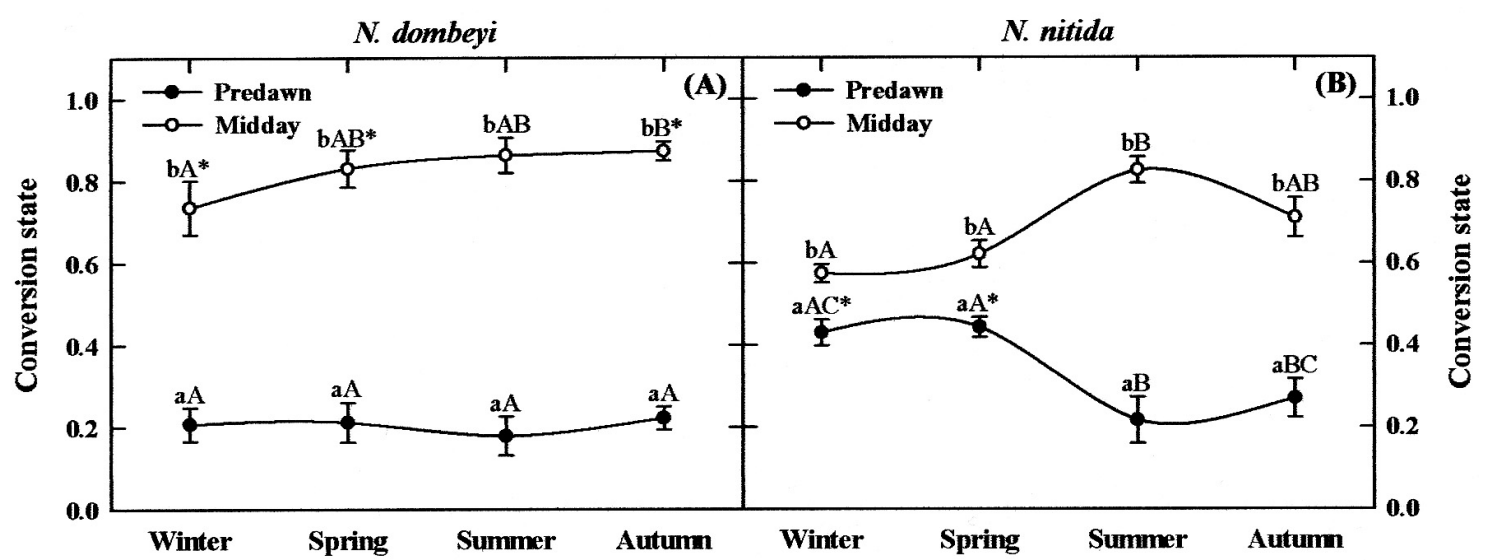

Fig. 3: Seasonal and daily changes of the conversion state $(\mathrm{A}+\mathrm{Z}) /(\mathrm{V}+\mathrm{A}+\mathrm{Z})$ of leaves of $N$. dombeyi (A) and $N$. nitida (B). Each point represents the mean of five replicates $\pm \mathrm{SE} ; \mathrm{V}=$ violaxanthin; $\mathrm{A}=$ antheraxanthin and $\mathrm{Z}=$ zeaxanthin. Different lower case letters indicate statistically significant differences $(\mathrm{P} \leq 0.05)$ between daily periods for each season and species. Different upper case letters show statistically significant differences $(\mathrm{P} \leq 0.05)$ between seasons for each species in the same daily period. Asterisk $(*)$ indicate statistically significant differences $(P \leq 0.05)$ between species for each parameter in the same season and hours of day.

Cambios estacionales y diarios en el estado de conversión $(\mathrm{A}+\mathrm{Z}) /(\mathrm{V}+\mathrm{A}+\mathrm{Z})$ de hojas de $N$. dombeyi (A) and $N$. nitida (B). Cada punto representa el promedio de cinco réplicas \pm EE para cada especie, estación y hora del día; $V=$ violaxantina; $\mathrm{A}=$ anteraxantina y $\mathrm{Z}=$ zeaxantina. Letras minúsculas diferentes indican diferencias estadísticamente significativas $(\mathrm{P} \leq 0,05)$ entre los períodos del día para cada estación y especie. Letras mayúsculas diferentes indican diferencias estadísticamente significativas $(\mathrm{P} \leq 0,05)$ entre las estaciones para cada especie en el mismo período del día. Asterisco $(*)$ indica diferencias estadísticamente significativas $(\mathrm{P} \leq 0,05)$ entre las especies, para cada parámetro en la misma estación y hora del día.

Fig. 4: Seasonal and daily changes in total soluble carbohydrates (A) and (B) and proline (C) and 


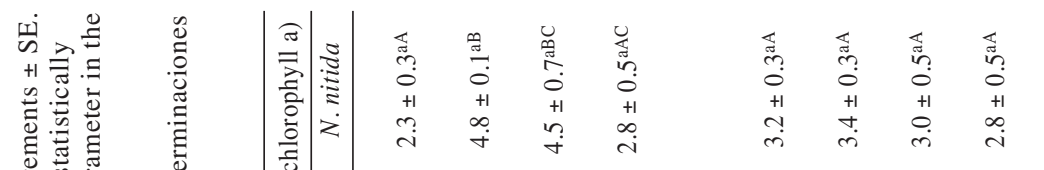

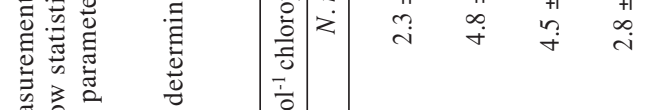

ते $\ddot{m} \stackrel{\circ}{\infty} \stackrel{\infty}{i}$

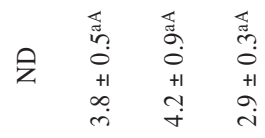

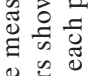

至离总

०० $\frac{0}{0}$

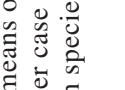

离

要空

焉离苛

iี

竞它

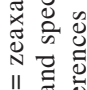

글

No

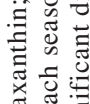

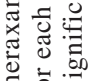

可

II

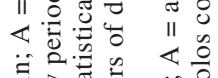

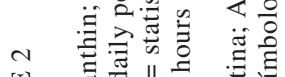

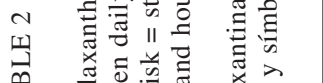

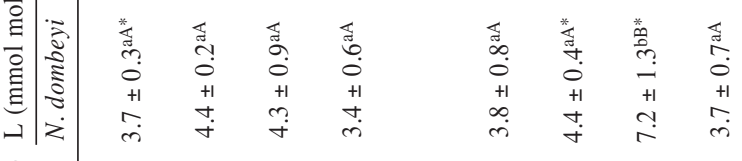

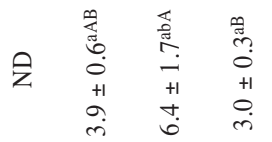

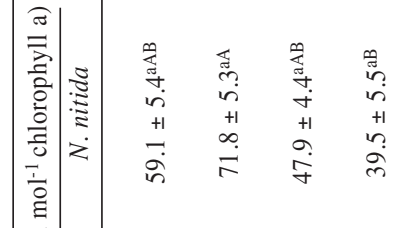

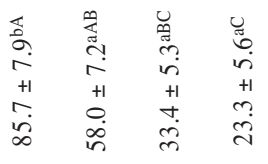

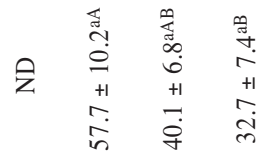

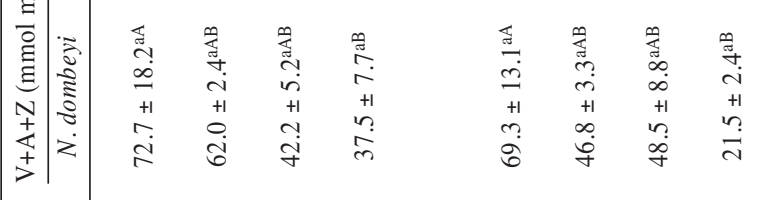

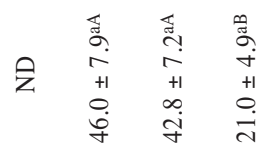

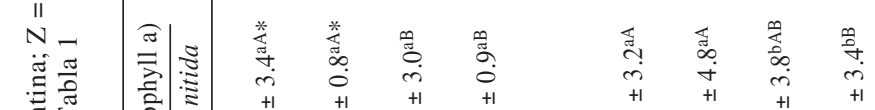

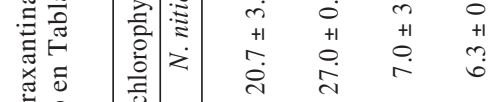

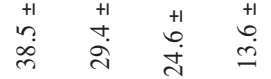

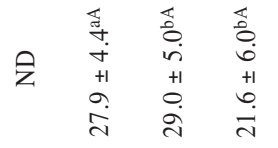

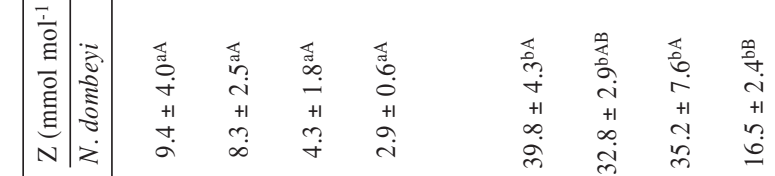

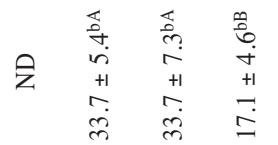

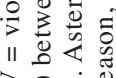

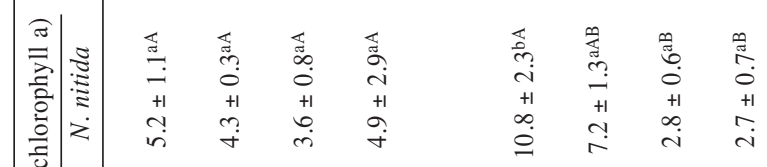

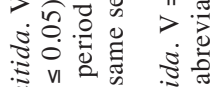

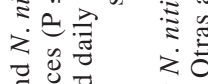

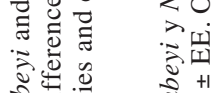

हิำ

之.

然齿

氜 䨌

$\exists .0$

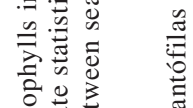

范造

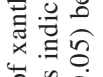

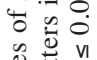

品竞 v

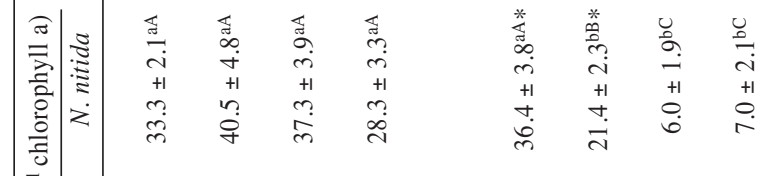

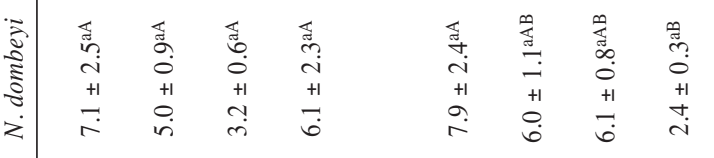

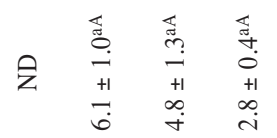

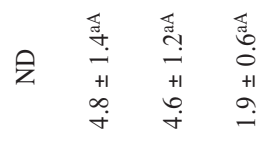

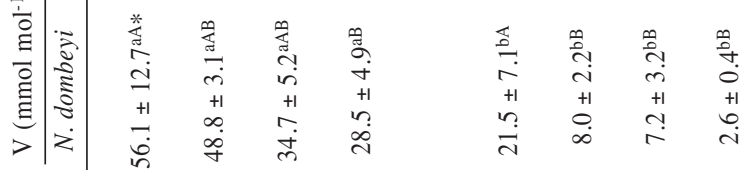

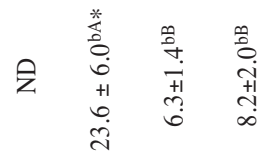
ำ 


\section{TABLE 3}

Seasonal and daily changes in the contents of total chlorophyll ( $\mathrm{Chl} \mathrm{a+b})$, chlorophyll a/ chlorophyll b $(\mathrm{Chl} \mathrm{a} / \mathrm{b})$ and carotenoids in leaves of $N$. dombeyi and $N$. nitida. Values are means of 5 replicates each \pm SE. Different lower case letters indicate statistically significant differences $(\mathrm{P} \leq$

$0.05)$ between daily periods for each season and species. Different upper case letters show statistically significant differences $(\mathrm{P} \leq 0.05)$ between seasons for each species and daily period.

Asterisk $(*)$ indicate statistically significant differences $(\mathrm{P} \leq 0.05)$ between species for each parameter in the same season and hours of the day. ND = not determined

Cambios estacionales y diarios en los contenidos de clorofila total (Chl a+b), clorofila a/ clorofila b (Chl a/b) y carotenoides en hojas de $N$. dombeyi y $N$. nitida. Valores son promedios de 5 réplicas \pm EE. Otras abreviaciones y símbolos como en Tabla 1

\begin{tabular}{|c|c|c|c|c|c|c|c|}
\hline \multirow[t]{2}{*}{ Time of day } & \multirow[t]{2}{*}{ Season } & \multicolumn{2}{|c|}{$\mathrm{Chl}$ a+b $\left(\mathrm{mg} \mathrm{g}^{-1} \mathrm{DW}\right)$} & \multicolumn{2}{|c|}{$\mathrm{Chl} \mathrm{a/b}$} & \multicolumn{2}{|c|}{ Carotenoids ( $\left.\mathrm{mg} \mathrm{g}^{-1} \mathrm{DW}\right)$} \\
\hline & & N. dombeyi & N. nitida & N. dombeyi & $N$. nitida & N. dombeyi & N. nitida \\
\hline \multirow{4}{*}{ Predawn } & Winter & $3.1 \pm 0.3^{\mathrm{aAB}}$ & $3.6 \pm 0.3^{\mathrm{aA}}$ & $4.4 \pm 0.1^{\mathrm{a} \mathrm{A}^{*}}$ & $4.0 \pm 0.1^{\mathrm{aAB}}$ & $0.8 \pm 0.1^{\mathrm{aA}}$ & $0.9 \pm 0.1^{\mathrm{aA}}$ \\
\hline & Spring & $4.0 \pm 0.2^{\mathrm{aA}}$ & $4.7 \pm 0.3^{\mathrm{aA}}$ & $4.1 \pm 0.2^{\mathrm{aA}^{*}}$ & $3.1 \pm 0.5^{\mathrm{aA}}$ & $1.2 \pm 0.1^{\mathrm{aB}}$ & $1.1 \pm 0.1^{\mathrm{aA}}$ \\
\hline & Summer & $3.2 \pm 0.3^{\mathrm{aAB}}$ & $4.1 \pm 0.7^{\mathrm{aA}}$ & $4.1 \pm 0.1^{\mathrm{a} \mathrm{A}^{*}}$ & $3.6 \pm 0.2^{\mathrm{aAB}}$ & $0.8 \pm 0.1^{\mathrm{aA}}$ & $1.0 \pm 0.1^{\mathrm{aA}}$ \\
\hline & Autumn & $2.6 \pm 0.3^{\mathrm{aB}}$ & $3.4 \pm 0.6^{\mathrm{aA}}$ & $4.3 \pm 0.1^{\mathrm{aA}}$ & $4.1 \pm 0.3^{\mathrm{aB}}$ & $0.7 \pm 0.1^{\mathrm{aA}}$ & $0.9 \pm 0.2^{\mathrm{aA}}$ \\
\hline \multirow{4}{*}{ Midday } & Winter & $3.2 \pm 0.5^{\mathrm{aA}}$ & $3.6 \pm 0.3^{\mathrm{aA}}$ & $4.0 \pm 0.1^{\mathrm{bAB}}$ & $3.8 \pm 0.1^{\mathrm{aA}}$ & $0.8 \pm 0.1^{\mathrm{aA}}$ & $0.9 \pm 0.1^{\mathrm{aA}}$ \\
\hline & Spring & $4.2 \pm 0.3^{\mathrm{aA}}$ & $4.3 \pm 0.4^{\mathrm{aA}}$ & $3.8 \pm 0.3^{\mathrm{aA}}$ & $3.6 \pm 0.3^{\mathrm{aA}}$ & $1.2 \pm 0.1^{\mathrm{aB}}$ & $1.1 \pm 0.1^{\mathrm{aA}}$ \\
\hline & Summer & $3.4 \pm 0.2^{\mathrm{aA}}$ & $4.5 \pm 0.6^{\mathrm{aA}}$ & $4.1 \pm 0.2^{\mathrm{aAB} *}$ & $3.6 \pm 0.2^{\mathrm{aA}}$ & $0.9 \pm 0.1^{\mathrm{aA}}$ & $1.0 \pm 0.2^{\mathrm{aA}}$ \\
\hline & Autumn & $3.2 \pm 0.2^{\mathrm{aA}}$ & $3.5 \pm 0.5^{\mathrm{aA}}$ & $4.7 \pm 0.3^{\mathrm{aB} *}$ & $3.7 \pm 0.2^{\mathrm{aA}}$ & $0.8 \pm 0.1^{\mathrm{aA}}$ & $0.8 \pm 0.1^{\mathrm{aA}}$ \\
\hline \multirow{4}{*}{ Afternoon } & Winter & ND & ND & ND & ND & ND & ND \\
\hline & Spring & $3.8 \pm 0.3^{\mathrm{aA}}$ & $4.5 \pm 0.3^{\mathrm{aA}}$ & $4.0 \pm 0.1^{\mathrm{aA}}$ & $3.9 \pm 0.2^{\mathrm{aAB}}$ & $1.1 \pm 0.1^{\mathrm{aA}}$ & $1.2 \pm 0.1^{\mathrm{aB}}$ \\
\hline & Summer & $3.4 \pm 0.2^{\mathrm{aA}}$ & $3.2 \pm 0.5^{\mathrm{aB}}$ & $4.0 \pm 0.2^{\mathrm{aA}}$ & $3.6 \pm 0.1^{\mathrm{aA}}$ & $0.9 \pm 0.0^{\mathrm{aAB}}$ & $0.8 \pm 0.1^{\mathrm{aA}}$ \\
\hline & Autumn & $3.1 \pm 0.3^{\mathrm{aA}}$ & $3.2 \pm 0.3^{\mathrm{aB}}$ & $4.3 \pm 0.1^{\mathrm{aA}}$ & $4.2 \pm 0.3^{\mathrm{aB}}$ & $0.8 \pm 0.1^{\mathrm{aB}}$ & $0.8 \pm 0.1^{\mathrm{aA}}$ \\
\hline
\end{tabular}

\section{Compatible solutes}

Seasonal differences between TSC in leaves of both species were found, being generally higher in $N$. dombeyi than $N$. nitida (Fig. 4A and 4B). In both species, winter TSC contents were higher than in other seasons $(\mathrm{P} \leq 0.05)$ with the exception of the morning values of $N$. dombeyi in summer, where TSC were similar to those found in winter. The seasonal and daily courses of proline content showed varied patterns of accumulation depending on time of day, season, and species (Fig. 4C and 4D). There was no clear tendency to accumulate proline in winter or summer. For example, the highest content of this compound was found in $N$. nitida in the morning in winter $(\mathrm{P} \leq 0.05)$, but rapidly decreased during the day. In contrast, in $N$. dombeyi, the highest content was found in the afternoon in autumn. Summer contents were relatively low in both species, being higher in $N$. nitida than in N. dombeyi.

\section{DISCUSSION}

The two investigated Nothofagus species presented significant differences in the physiology of the photosynthetic apparatus. The optimal photochemical efficiency ( $\mathrm{Fv} / \mathrm{Fm})$ in both species was frequently located within the normal physiological values (around 0.8) throughout the year (Björkman \& Demmig 1987). However, in the driest season and at the time with the highest PPFD (midday), $N$. dombeyi leaves showed a small (15\%) but statistically significant $(\mathrm{P} \leq 0.05)$ decrease in Fv/Fm. According to Krause \& Winter (1996) and Hüner et al. (2002), this decrease in Fv/Fm can not be interpreted as photoinhibition of the photosynthetic apparatus. Other reports sustained that for evergreen angiosperms a decrease in $\mathrm{Fv} / \mathrm{Fm}$ below 0.83 indicates inactivation of PSII (Björkman \& Demmig 1987). In our study, concomitantly with the midday decrease in $\mathrm{Fv} / \mathrm{Fm}$ with respect to 
predawn in summer in $N$. dombeyi, an increase in $\Phi_{\mathrm{PSII}}, \mathrm{qP}$, and $\mathrm{CO}_{2}$ assimilation was found ( $\mathrm{P}$ $\leq$ 0.05) (Table 1 and Fig. 2A). These physiological parameters are indicators of the stability of PSII. Thus, we can not assume a similar inactivation of PSII, compared to that observed in winter and summer in other species in the field (Adams \& Demmig-Adams 1994). The decrease in Fv/Fm in $N$. dombeyi from 0.85 in predawn to 0.73 at midday does not seem to negatively affect the functionality of PSII Lower mean Fv/Fm values (0.55 to 0.61 ) are found at midday in summer in some evergreen species that are able to down regulate their photochemical efficiency (Adams \& DemmigAdams 1994). Conversely, at midday in summer, in $N$. nitida, $\mathrm{Fv} / \mathrm{Fm}$ values were higher than in $N$. dombeyi despite lower $\Phi_{\text {PSII }}$, qP. It appears, however, that under high PPFD (midday) in the dryer season, N. dombeyi

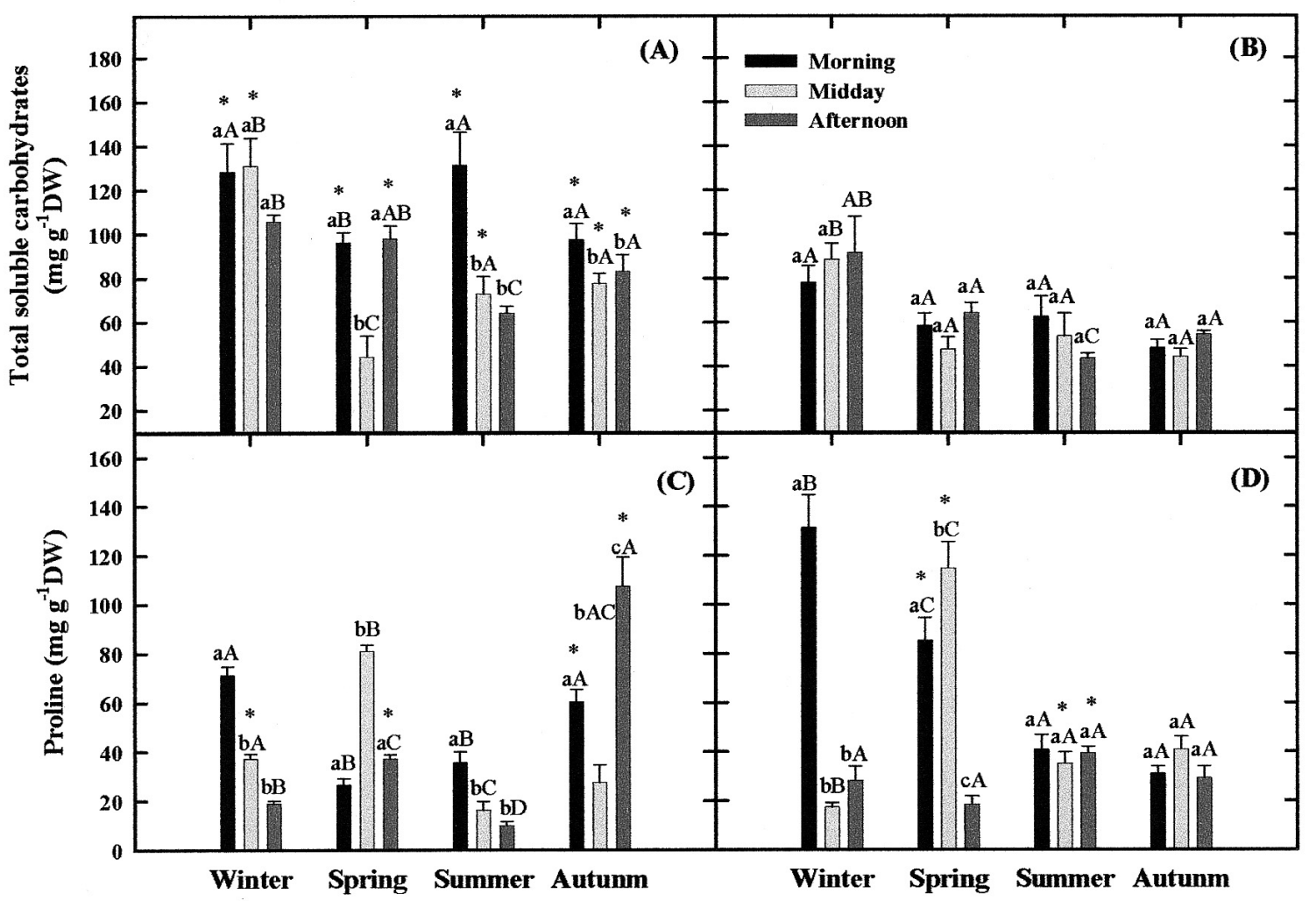

(D) contents in leaves of $N$. dombeyi and $N$. nitida, respectively. Morning measurements were made one or two hours after dawn (morning). Midday measurements were made at the time of the highest temperature and PPFD (between 12 and $14 \mathrm{~h}$ ). Afternoon measurements were made two hours before sunset. Values represent the means of five replicates in each species, season and daily period \pm SE. Different lower case letters indicate statistically significant differences $(P \leq 0.05)$ between daily periods for each season and species. Different upper case letters show statistically significant differences $(\mathrm{P} \leq 0.05)$ between seasons for each species in the same daily period. Asterisk $(*)$ indicate statistically significant differences $(\mathrm{P} \leq 0.05)$ between species for each parameter in the same season and hours of day.

Cambios estacionales y diarios en los contenidos en carbohidratos solubles totales (A) y (B) y prolina (C) y (D) en hojas de $N$. dombeyi y $N$. nitida, respectivamente. Mediciones fueron hechas una o dos horas después del alba (mañana), en el período de mayor temperatura y PPFD (mediodía), entre las 12 y $14 \mathrm{~h}$, y dos horas antes de la puesta del sol (tarde). Valores representan el promedio de cinco réplicas en cada especie y estación \pm EE. Letras minúsculas diferentes indican diferencias estadísticamente significativas $(\mathrm{P} \leq 0,05)$ entre las horas del día, para cada estación y especie. Letras mayúsculas diferentes muestran diferencias estadísticamente significativas $(\mathrm{P} \leq 0,05)$ entre las estaciones para cada especie en el mismo período del día. Asterisco $(*)$ indica diferencias estadísticamente significativas $(\mathrm{P} \leq 0,05)$ entre especies, para cada parámetro en la misma estación y hora del día. 
utilizes light energy for photochemical processes more efficiently than $N$. nitida, which corresponds well with the higher $\mathrm{CO}_{2}$ assimilation of this species in comparison with N. nitida $(\mathrm{P} \leq 0.05)$. This highly efficient behavior of $N$. dombeyi in the utilization of absorbed energy in the photochemical and $\mathrm{CO}_{2}$ assimilation processes at the highest PPFD (summer) coincides with higher contents in $\mathrm{Z}$ (8.2-fold higher) and slightly higher contents in A and L (1.9 and 1.7-fold higher, respectively) in relation to predawn (Table 2). Similar results are reported for other plants exposed to high light and to additional stresses such as drought or cold (Faria et al. 1996, Logan et al. 1998, Verhoeven et al. 1999, García-Plazaola et al. 2003).

Differently as occurs in $N$. dombeyi, in upper canopy leaves of Nothofagus cunninghamii from an Australian rainforest subjected to high irradiance (by simulated sunflecks) the decrease of the Fv/Fm and the increase of $\mathrm{Z}$, is associated with a transitory decrease of $\Phi_{\text {PSII }}$ and net photosynthesis (Tausz et al. 2005). In winter $\mathrm{Z}$ also accumulated more in $N$. dombeyi (4.2-fold higher) than in $N$. nitida (1.8-fold higher) at the time of high PPFD in relation to predawn. This represents a typical photoprotective strategy by which overwintering leaves prevent reactive oxygenmediated damage, whereby the excess light energy absorbed by chlorophyll is dissipated as harmless heat (Adams et al. 2004). Nothofagus dombeyi is dependent on light for the transformation of the xanthophylls pool in $\mathrm{Z}$ from predawn to midday in winter and spring. In $N$. nitida a conservation of some proportions of $\mathrm{Z}$ remained overnight until midday (Fig. 3 and Table 2), suggesting a nocturnal retention of dissipative pigments in this species as occurred in other plants (Logan et al. 1998, Verhoeven et al. 1999). This effect has been explained by a stimulating cold effect, which contributes to keep an acidic intrathylakoid $\mathrm{pH}$, which could maintain active to some extent the enzyme violaxanthin de-epoxidase at night. Thus, the generation of $\mathrm{Z}$ could then contribute to photoprotection during the day (Verhoeven et al. 1998, Barker et al. 2002). Mahonia repens populations exposed to direct sunlight in winter showed a nocturnal retention of $\mathrm{Z}$ at predawn, which was associated with sustained depressions in $\mathrm{Fv} / \mathrm{Fm}$ (Logan et al. 1998). In contrast, Fv/Fm did not decrease in $N$. nitida despite the nocturnal retention of $\mathrm{Z}$. The highest increments in $\mathrm{Z}+\mathrm{A}$ contents between predawn and midday in $N$. dombeyi were obtained in summer (450\%), while in N. nitida this increase was lower $(158 \%)$. This increase is mainly due to the increment in $\mathrm{Z}$. This suggests that dynamic changes in the photosynthetic apparatus of these species from winter to summer occur, being these changes more notorious in $N$. dombeyi than in $N$. nitida. Other difference between these species was the larger predawn and midday NPQ found in summer and autumn in $N$. dombeyi (Table 1), corresponding with a larger conversion state (Fig. 3) That could explain the heliophyte character of $N$. dombeyi with respect to $N$. nitida.

In contrast to the behavior of evergreen species from colder climates, where $\mathrm{CO}_{2}$ fixation rates close to zero were found in winter (Strand et al. 2002), our subject species showed a positive $\mathrm{CO}_{2}$ balance in this season. In a Mediterranean climate, a depression in net photosynthesis was found in Quercus suber in winter, although the major depression occurred in summer (García-Plazaola et al. 1997) concomitantly with stomatal closure, due to drought. In our study, $N$. dombeyi did not show stomatal closure at midday in summer, which is the time of highest photosynthesis (Fig. 2A and 2B). Nothofagus nitida closed its stomata towards the afternoon, but maintained its midday photosynthetic rate (Fig. $2 \mathrm{E}$ and $2 \mathrm{~F}$ ). This stomatal behavior caused lower leaf transpiration of $N$. nitida than $N$. dombeyi at midday $(\mathrm{P} \leq 0.05)$. Despite that, $N$. dombeyi maintains similar relative water contents than $N$. nitida (data not shown). The ability to maintain opened stomata for a longer time permits not only water vapor exchange, but the uptake of $\mathrm{CO}_{2}$ which conduces to higher photosynthesis (Larcher 2003). In addition, $N$. dombeyi exhibited higher WUE than $N$. nitida under high light intensities in the dry season. These results are consistent with those of Weinberger et al. (1973), where a higher capacity to loose water and tolerate desiccation without leaf lethal injury was found for $N$. dombeyi rather than $N$. nitida. The higher photosynthetic rates found in $N$. dombeyi at midday and afternoon in summer corresponded well with higher $\mathrm{qP}, \Phi_{\mathrm{PSII}}$, indicating a better 
photosynthetic performance under this environmental conditions in this species than in $N$. nitida. This behavior is consistent with the preference of $N$. dombeyi for open spaces, as opposed to $N$. nitida, which regenerates in shady habitats.

The lack in total chlorophyll content changes during the daily cycle at all seasons in both species could indicate that a mechanism to avoid or decrease energy absorption throughout the decrease in chlorophyll contents is not exhibited by these species, contrarily to the behavior in most of sun-exposed leaves of evergreen species (Adams \& Barker 1998, Adams et al. 2002). This behavior could be explained as a response to the high frequency of cloudy and rainy days in the study site.

The higher accumulation of TSC in winter in both species could be explained by a low temperature effect on the enzymatic mobilization of starch to soluble sugars as found in other woody plants (Sakai \& Larcher 1987). It is known that an accumulation of some osmolytes such as carbohydrates and proline can contribute to confer cold resistance to plants preventing frost injury (Larcher 2003). TSC results correspond well with a higher freezing tolerance found in winter in these species, which was higher in $N$. dombeyi than in N. nitida (Reyes-Díaz et al. 2005). There is not a clear relationship between proline contents and freezing tolerance. There is evidence that the major changes in total osmotic potential $\left(\Psi_{\pi}\right)$ which accompany the seasonal course of freezing tolerance are due to changes in sugar contents during the seasonal cycle (Sakai \& Larcher 1987). In our study, the winter carbohydrate accumulation did not parallel well with the lowest $\Psi_{\pi}$. On the contrary, $\Psi_{\pi}$ were significantly lower in summer $(-1.93 \mathrm{MPa})$ in $N$. dombeyi than in winter (-1.61 MPa) (not shown) probably, due to a lower water availability in these seasons and a higher $\mathrm{E}$ than in N. nitida (Fig. 1, Fig. 2C and $2 \mathrm{G})$.

We conclude, that $N$. dombeyi showed a better photosynthetic performance, accompanied by higher accumulation of photoprotective pigments of the xanthophylls cycle, than $N$. nitida in summer under the highest light intensity, temperature and the driest conditions. Under wet conditions both species, in particular $N$. nitida showed good photosynthetic performance. These evidences could help to explain the heliophyte and pioneer character of $N$. dombeyi and the decreased shade semi-tolerant properties of adult individuals of $N$. nitida that emerge from the canopy. Thus, light use and management are two of the factors that appear to contribute to habitat separation of these two species. Differential freezing, water and flooding stress resistance of the two species could also contribute to their habitat separation. Nonetheless, further studies should be conducted on the differential resistance of these two species to water and flooding stress.

\section{ACKNOWLEDGEMENTS}

The authors thank FONDECYT 1030663 and DID-UACH S-2004-2 for financial support and to Valeria Neira and Viviana Morales for technical assistance. MR was funded by a doctoral fellowship granted by CONICYT.

\section{LITERATURE CITED}

ADAMS WW \& B DEMMIG-ADAMS (1994) Carotenoid composition and down-regulation of photosystem-II in three conifer species during the winter. Physiologia Plantarum 92: 451-458.

ADAMS WW \& DH BARKER (1998) Seasonal changes in xanthophyll cycle-dependent energy dissipation in Yucca glauca Nuttall. Plant, Cell and Environment 21: 501-511.

ADAMS WW, B DEMMIG-ADAMS, TN ROSENSTIEL, AK BRIGHTWELL \& V EBBERT (2002) Photosynthesis and photoprotection in overwintering plants. Plant Biology 4: 545-557.

ADAMS WW, CR ZARTER, V EBBERT \& B DEMMIGADAMS (2004) Photoprotective strategies of overwintering evergreens. Bioscience 54: 41-49.

ALBERDI M, M ROMERO, D RÍOS \& H WENZEL (1985) Altitudinal gradients of seasonal frost resistance in Nothofagus communities of southern Chile. Acta Oecologica-Oecologia Plantarum 6: 21 30.

BARKER DH, WW ADAMS, B DEMMIG-ADAMS, BA LOGAN, AS VERHOEVEN \& SD SMITH (2002) Nocturnally retained zeaxanthin does not remain engaged in a state primed for energy dissipation during the summer in two Yucca species growing in the Mojave Desert. Plant, Cell and Environment 25: 95-103.

BATES LS, RP WALDREN \& ID TEARE (1973) Rapid determination of free proline for water stress studies. Plant and Soil 39: 205-207.

BJÖRKMAN O \& B DEMMIG (1987) Photon yield of $\mathrm{O}_{2}$ evolution and chlorophyll fluorescence characteristics at $77 \mathrm{~K}$ among vascular plants of diverse origins. Planta 170: 489-504. 
CABRERA HM (2002) Respuestas ecofisiológicas de plantas en ecosistemas de zonas con clima mediterráneo y ambientes de alta montaña. Revista Chilena de Historia Natural 75: 625-637.

DEMMIG-ADAMS B (2003) Linking the xanthophylls cycle with thermal energy dissipation. Photosynthesis Research 76: 73-80.

DEMMIG B, K WINTER, A KRÜGER \& FC CZYGAN (1988) Zeaxanthin and the heat dissipation of excess light energy in Nerium oleander exposed to a combination of high light and water stress. Plant Physiology 87: 17-24.

DI CASTRI F \& E HAJEK (1976) Bioclimatología de Chile. Vicerrectoría Académica, Universidad Católica de Chile, Santiago, Chile. 128 p.

DONOSO C \& A LARA (1998) Silvicultura de los bosques nativos de Chile. Primera edición. Editorial Universitaria, Santiago, Chile. $421 \mathrm{p}$

FARIA T, JI GARCÍA-PLAZAOLA, A ABADÍA, S CERASOLI, JS PEREIRA \& MM CHAVES (1996) Diurnal changes in photoprotective mechanisms in leaves of cork oak (Quercus suber) during summer. Tree Physiology 16: 115-123.

GARCÍA-PLAZAOLA JI, T FARIA, J ABADÍA, A ABADÍA, M CHAVES \& J PEREIRA (1997) Seasonal changes in xanthophyll composition and photosynthesis of cork oak (Quercus suber L.) leaves under Mediterranean climate. Journal of Experimental Botany 48: 1667-1674.

GARCÍA-PLAZAOLA JI, JM OLANO, A HERNÁNDEZ \& JM BECERRIL (2003) Photoprotection in evergreen Mediterranean plants during sudden periods of intense cold weather. Trees-Structure and Function 17: 285-291

GENTY B, JM BRIANTAIS \& NR BAKER (1989) The relationship between the quantum yield of photosynthetic electron-transport and quenching of chlorophyll fluorescence. Biochimica et Biophysica Acta 990: 87-92.

GILMORE AM \& HY YAMAMOTO (1991) Resolution of lutein and zeaxanthin using a non-endcapped, lightly carbon-loaded C-18 high-performance liquid-chromatographic column. Journal of Chromatography 543: 137-145.

HÜNER NPA, AG IVANOV, KE WILSON, MM KROLL \& G ÖQUIST (2002) Energy sensing and photostasis in photoautrophs. In: Storey KB \& JM Storey (eds) Cell and molecular responses to stress: sensing signaling and cell adaptation: 243-255. Elsevier Science, Amsterdam, The Netherlands.

KRAUSE GH \& K WINTER (1996) Photoinhibition of photosynthesis in plants growing in natural tropical forest gaps. A chlorophyll fluorescence study. Botanica Acta 109: 456-462.

KÜLHEIM C, J ÅGREN \& S JANSSON (2002) Rapid regulation of light harvesting and plant fitness in the field. Science 297: 91-93.

LARCHER W (2000) Temperature stress and survival ability of Mediterranean sclerophyllous plants. Plant Biosystems 134: 279-295.

LARCHER W (2003) Plants under stress. In: Larcher W (ed) Physiological plant ecology: 345-450. Springer-Verlag, Berlin, Germany.

LICHTENTHALER H \& AR WELLBURN (1983) Determinations of total carotenoids and chlorophyll $a$ and $b$ of leaf extracts in different solvents. Biochemical Society Transactions 603: 591-592.

LOGAN BA, SC GRACE, WW ADAMS \& B DEMMIGADAMS (1998) Seasonal differences in xanthophyll cycle characteristics and antioxidants in Mahonia repens growing in different light environments. Oecologia 116: 9-17.

LUSK CH \& A DEL POZO (2002) Survival and growth of seedlings of 12 Chilean rainforest trees in two light environments: gas exchange and biomass distribution correlates. Austral Ecology 27: 173-182.

MC QUEEN DR (1977) The ecology of Nothofagus and associated vegetation en South America. Tuatara 22: $233-244$

MÜLLER P, XP LI \& KK NIYOGI (2001) Nonphotochemical quenching. A response to excess light energy. Plant Physiology 125: 1558-1566.

MUNNÉ-BOSCH S \& L ALEGRE (2000) The xanthophyll cycle is induced by light irrespective of water status in field-grown lavender (Lavandula stoechas) plants. Physiologia Plantarum 108: 147-151.

NIYOGI KK (1999) Photoprotection revisited: genetic and molecular approaches. Annual Review of Plant Physiology and Plant Molecular Biology 50: 333359.

PASCAL AA, ZF LIU, K BROESS, B VAN OORT, H VAN AMERONGEN, C WANG, P HORTON, B ROBERT, WR CHANG \& A RUBAN (2005) Molecular basis of photoprotection and control of photosynthetic light-harvesting. Nature 436: 134137.

REYES-DÍAZ M, M ALBERDI, F PIPER, LA BRAVO \& LJ CORCUERA (2005) Low temperature responses of Nothofagus dombeyi (Mirb.) Blume and Nothofagus nitida (Phil.) Krasser, two evergreen species from south central Chile. Tree Physiology 25: $1389-1398$.

ROE JH (1934) A colorimetric method for the determination of fructose in blood and urine. Journal of Biological Chemistry 107: 15-22.

SAKAI A \& W LARCHER (1987) Frost survival of plants. Responses and adaptation to freezing stress. Springer, Berlin, Germany. 321 pp.

STANDFUSS J, ACT VAN SCHELTINGA, M LAMBORGHINI \& W KÜHLBRANDT (2005) Mechanisms of photoprotection and non photochemical quenching in pea light-harvesting complex at $2.5 \AA$ resolution. EMBO Journal 24: 919-928.

STRAND M, T LUNDMARK, I SÖDERBERGH \& PE MELLANDER (2002) Impacts of seasonal air and soil temperatures on photosynthesis in Scots pine trees. Tree Physiology 22: 839-847.

TAUSZ M, CR WARREN \& AA ADAMS (2005) Dynamic use and protection from excess light in upper canopy and coppice leaves of Nothofagus cunninghamii in an old growth, cool temperate rainforest in Victoria, Australia. New Phytologist 165: 143-156.

VAN KOOTEN O \& JFH SNEL (1990) The use of chlorophyll fluorescence nomenclature in plant stress physiology. Photosynthesis Research 25: 147-150.

VEBLEN TT, T KITZBERGER, BR BURNS \& AJ REBERTUS (1995) Perturbaciones y dinámica de regeneración en bosques andinos del sur de Chile y Argentina. In: Armesto JJ, C Villagrán, M KalinArroyo (eds) Ecología de los bosques nativos de Chile: 169-198. Editorial Universitaria, Santiago, Chile.

VEBLEN TT, C DONOSO, T KITSBERGER \& AJ REBERTUS (1996) Ecology of southern Chilean and Argentinean Nothofagus forests. In: Veblen TT, RS Hill, RJ Yale (eds) The ecology and biogeography of Nothofagus forests: 293-353. Yale University Press, New Haven, USA. 
VERHOEVEN AS, WW ADAMS \& B DEMMIG-ADAMS (1998) Two forms of sustained xanthophyll cycledependent energy dissipation in overwintering Euonymus kiautschovicus. Plant, Cell and Environment 21: 893-903.

VERHOEVEN AS, WW ADAMS \& B DEMMIG-ADAMS (1999) The xanthophyll cycle and acclimation of Pinus ponderosa and Malva neglecta to winter stress. Oecologia 118: 277-287.

Associate Editor: Julio Gutiérrez

Received March 3, 2006; accepted July 13, 2006
WEINBERGER P (1973) Beziehungen zwischen mikroklimatische Faktoren und natürlicher Verjüngung araukano-patagonischer NothofagusArten. Flora 162: 157-179.

WEINBERGER P, L ROMERO \& M OLIVA (1973) Untersuchungen über die Dürreresistenz patagonischer-immergrüner Gehölze. Vegetatio 28: $75-98$. 